\title{
DAMPAK EKONOMI DARI PENERAPAN SISTEM BIOMETRIK DI KALANGAN PNS PERGURUAN TINGGI ISLAM NEGERI
}

\author{
Heny Yuningrum ${ }^{1}$
}

\begin{abstract}
Abstrak
Kinerja peagawi negeri sipil saat ini menjadi sorotan publik. Hal ini dikarenakan banyak perilaku dari mereka yang tidak bernaan dengan aturan yang ada. Majas hiperbola menjadi hasutan bagi para PNS. Perbitungan kinerja PNS sangat berkaitan dengan system keuangan Negara. Hal ini dapat dilihat dari jumlah kehadiran mereka saat bekerja. Penerapan system biometric merupakan system yang tepat untuk menghitung tingkat kedisiplinan PNS.

Penerapan alat digital ini memberikan dampak ekonomi bagi PTAIN. Hubungannya adalah dengan kompensasi yang akan diberikan. Semakin tepat waktu dalam absensi maka semakin banyak kompensasi yang akan diterima, dan begitu sebaliknya. Pemerintah memberikan nominal uang kompensasi disesuaikan dengan jumlah kehadiran PNS dalam bekerja. Dampak penerapan system ini sangat mempengarubi jumlah nominal kompensasi yang diberikan pemerintah kepada pegawai.
\end{abstract}

Keyword : system biomterik, kompensasi

\section{Pendahuluan}

Peningkatan kinerja dalam bekerja sangat dianjurkan dalam Agama begitu juga dianjurkan oleh semua instansi pemerintah, perusahaan maupun organisasi kelembagaan. Dengan adanya kinerja yang optimal maka aspekaspek lembaga pun akan tercapai tujuan yang maksimal. Aspek-aspek tersebut mulai dari aspek kepegawaian, aspek keuangan, aspek produksi, aspek marketing, dan aspek-aspek yang terkait perusahaan atau lembaga tersebut. Pengukuran kinerja pegawai menurut Dwiyanto (dalam Pasolong, 2006: 5051) bahwa indicator yang digunakan untuk mengukur kinerja adalah sebagai berikut :

a. Produktivitas,

${ }^{1}$ Dosen Fakultas Ekonomi dan Bisnis Islam IAIN Walisongo Semarang

Volume V/Edisi 1/Mei 2014 
Dampak Ekonomi dari Penerapan Sistem Biometrik

b. Kualitas layanan,

c. Responsivitas,

d. Responsibilitas,

e. Akuntabilitas,

Dari beberapa indicator tersebut pada dasarnya diperlukan kerja keras yang tinggi dari aspek-aspek kepegawaian, pimpinan bahkan dari diri pribadi pegawai tersebut. Terkadang pimpinan instansi terkait telah memberikan pelatihan-pelatihan, workshop, lokakarya hingga pemberian kompensasi untuk kepentingan meningkatkan disiplin dan kinerja pegawai dan dosen yang diharapkan juga dapat meningkatkan semangat kerja mereka.

Dorongan semangat kepada pegawai sangat dibutuhkan supaya kinerjanya pun semakin meningkat. Motivasi pimpinan kepada pegawai dan dosen sangat dibutuhkan untuk meningkatkan semangat kerja mereka yang secara tidak langsung juga meningkatkan kinerja mereka. Penilaian ke

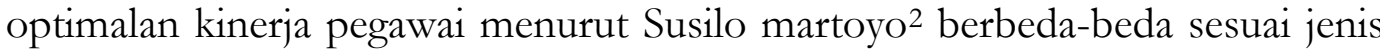
jabatan, bidang pekerjaan. Dapat disimpulkan dari berbagai perbedaan tersebut memiliki tujuan yaitu $:^{3}$

1. Untuk mengidentifikasi para karyawan mana yang membutuhkan pendidikan dan latihan.

2. Menetapkan kenaikan gaji ataupun upah.

3. Menetapkan kemungkinan pemindahan karyawan ke penugasan baru.

4. Menetapkan kebijaksanaan baru dalam rangka reorganisasi.

5. Mengidentifikasi para karyawan yang akan dipromosikan ke jabatan yang lebih tinggi dan sebagainya.

Kinerja pada dasarnya merupakan hasil kerja secara kualitas dan kuantitas yang dicapai seorang pegawai dalam melaksanakan tugasnya sesuai tanggung jawab yang diberikan kepadanya. Dalam hal ini, pegawai bisa belajar seberapa besar kinerja mereka melalui sarana informasi seperti komentar baik dari mitra kerja. Namun demikian penilaian kinerja yang mengacu kepada suatu sistem formal dan terstruktur yang mengukur, menilai dan mempengaruhi sifat-sifat yang berkaitan dengan pekerjaan perilaku dan hasil

${ }^{2}$ Susilo Martoyo. Kol. (Purn), SE.,hal: 97, Manajemen Sumber Daya Manusia edisi 4, BPFE, Yogjakarta.

${ }^{3}$ Ibid, hal : 95 
termasuk tingkat ketidakhadiran. Fokus penilaian kinerja adalah untuk mengetahui seberapa produktif seorang karyawan dan apakah ia bisa berkinerja sama atau lebih efektif di masa yang akan datang.

Begitu pentingnya masalah kinerja pegawai ini, sehingga tidak salah bila inti pengelolaan sumber daya manusia adalah bagaimana mengelola kinerja SDM. Mengelola manusia dalam konteks organisasi berarti mengelola manusia agar dapat menghasilkan kinerja yang optimal bagi organisasi. Oleh karenanya kinerja pegawai ini perlu dikelola secara baik untuk mencapai tujuan organisasi, sehingga menjadi suatu konsep manajemen kinerja (performance management).

Salah satu mengukur tinggi rendahnya kinerja seseorang adalah dapat dilihat dari kedisiplinan kedatangan yang bersangkutan dalam bekerja. Baik itu berupa ketepatan jam masuk kerja hingga ketepatan dia pulang bekerja, atau dari segi ketepatan dan kecepatan dia mengerjakan suatu pekerjaan yang ditugaskan atasan kepadanya. Jika semua itu dapat dilaksanakan dengan baik maka pegawai tersebut dapat digolongkan pada pegawai yang memilliki kinerja yang tinggi. Hal yang berkaitan dengan kedisiplinan waktu bekerja dalam hal ini adalah absensi pegawai merupakan sesuatu hal yang paling utama dalam mengukur kinerja seseorang. Terbukti dari beberapa penelitian terdahulu menghubungkan absensi kerja dengan kinerja pegawai. Sebagai contoh penelitian dari Erna Maeyasari seorang alumni dari Sultan Ageng Tirtayasa Serang tahun 2012. Menyatakan bahwa penerapan absensi finger print di Sekretariat Daerah Kabupaten Lebak hanya efektif 35,2 \% pada tingkat kedisiplinan pegawainya sedangkan 64,8\% dipengaruhi oleh variable lain selain alat biometric. Sehingga system finger print atau system biometric dapat digunakan untuk pengukuran kedisiplinan seseorang dalam mentaati waktu bekerja.

System biometric merupakan sistem yang sedang fenomenal di terapkan di lembaga pemerintahan maupun perusahaan sekarang ini. Dari sistem biometric tersebut dapat diketahui tingkat kedislipinan pengawai dalam bekerja. Tingkat kedisiplinan melalui system biometric dilihat dari jam berangkat kerja hingga jam pulang kerja. Jika sesuai aturan jam kerja yang telah ditentukan oleh lembaga atau perusahaan maka pegawai tersebut dinilai disiplin, sedangkan kebalikannya jika tidak sesuai lamanya aturan jam kerja maka pegawai tersebut dikatakan tidak disiplin. Penilaian ketidak disiplinan 


\section{Dampak. Ekonomi dari Penerapan Sistem Biometrik}

pegawai dapat menjadi catatan lembaga atau perusahaan untuk menilai kinerja pegawai ke depannya. Salah satu cara mengukur tingkat kedislinan dan kinerja pegawai yaitu dapat dilihat dari absensi kehadiran pegawai tersebut. System biometric ada tiga macam yaitu finger print, hand print dan eyes print.

Sistem biometric finger print yang digunakan untuk absensi kehadiran adalah jari tangan, hand print merupakan absensi digital dengan menggunakan telapak tangan sedangkan eyes print yang digunakan adalah corak mata. Dimana setiap manusia memiliki corak garis jari tangan, corak telapak tangan dan corak mata yang berbeda-beda sehingga anggota tubuh inilah yang sering digunakan untuk mengidentifikasi seseorang.

Banyak wacana dari berbagai pegawai instansi pemerintahan bahwa terdapat beberapa pegawai yang hasil absensi finger printnya terkalkumulasi penuh dalam sebulan namun saat jam kerja siang yang bersangkutan tidak berada di tempat kerja. Dengan adanya isu-isu seperti itu pihak pemerintah akhirnya memperketat aturan kerja. Seperti aturan yang dikeluarkan dari Kementerian Agama Nomor 28 Tahun 2013 tentang Disiplin Kehadiran Pegawai Negeri Sipil Di lingkungan Kementerian Agama. Dikeluarkannya aturan tersebut pemerintah memiliki harapan agar kedisiplinan pegawai di lingkungan Kementerian Agama semakin meningkat. Aturan tersebut dikeluarkan berkaitan juga dengan kompensasi uang makan yang akan diterima para pegawai tersebut. Jika kediplinan pegawai rendah maka tidak seharusnya mendapatkan kompensasi yang sepantasnya.

Kompensasi ini diberikan dengan tujuan dapat menarik pegawai atau karyawan untuk mempertahankan dan meningkatkan kinerjanya dalam bekerja sehingga kompensasi disini dapat dikatakan sebagai motivator suatu instansi atau lembaga tempat dia bekerja. Kompensasi yang pada umumnya diberikan perusahaan ialah berupa gaji untuk karyawannya. Namun, sebenarnya kompensasi yang diberikan perusahaan tidak hanya berupa gaji, namun dapat dikelompokkan menjadi : ${ }^{4}$

1. Kompensasi Finansial Langsung

${ }^{4}$ Ismi Herdyanti, Hubungan Kompensasi Dengan Kinerja Karyawan, Universitas Gunadharma, 2013 
Kompensasi langsung ini dapat berupa bayaran pokok (gaji), bayaran atas prestasi yang telah diberikan karyawan untuk perusahaan, juga dapat berupa bayaran insentif.

2. Kompensasi Finansial Tidak Langsung

Yang termasuk kompensasi tidak langsung yaitu dapat berupa tunjangantunjangan, asuransi, kesehatan, juga fasilitas lainnya yang diberikan perusahaan seperti kendaraan, ruang kerja, dan lain-lain diluar gaji pokok, upah, dan bonus.

3. Kompensasi Non Finansial

Berbeda dengan kompensasi finansial langsung maupun tidak langsung, kompensasi non finansial ini tidak berupa uang ataupun tunjangan, melainkan kepuasan yang diperoleh oleh pekerja itu sendiri karena lingkungan psikologis dan fisik dari tempat kerjanya.

Dari beberapa bentuk tersebut diatas yang sedang fenomenal dilaksanakan adalah uang makan, sertifikasi dan remunerasi. Perhitungan ketiga kompensasi tersebut berbeda. Uang makan dihitung dari tingkat kehadiran atau absensi pegawai dan diberikan kepada semua pegawai negeri sipil di lingkungan Kementerian. Sertifikasi dihitung berdasarkan kinerja pegawai negeri sipil dalam satu semester atau satu tahun pengajaran mulai dari aspek pengajaran, penelitian, pengabdian masyarakat dan aspek tambahan. Sertifikasi diberikan khusus kepada guru dan dosen yang berkualifikasi. Sedangkan remunerasi diberikan kepada semua pegawai negeri sipil yang dihitung dari tingkat kehadiran atau absensi pegawai tersebut. Sedangkan uang makan dihitung dari jumlah kehadiran (absensi) per bulannya melalui print out finger print dan diberikan kepada semua pegawai yang bekerja di instansi tersebut.

IAIN Walisongo Semarang merupakan salah satu Perguruan Tinggi Agama Islam yang menggunakan finger print sebagai alat absensi digital untuk mengetahui kehadiran pegawai dan dosen di lingkungan IAIN Walisongo. Dari hasil print out finger print dapat diketahui pegawai atau dosen mana yang tingkat kehadirannya sesuai aturan UU No 28 Tahun 2013 atau tidak sesuai aturan pemerintah. Jumlah pegawai dan dosen di IAIN Walisongo adalah 552 
Dampak Ekonomi dari Penerapan Sistem Biometrik

orang. Dan dari 552 orang tersebut dari kalangan pimpinan sampai bawahan harus melakukan absensi di saat masuk kerja sampai pulang kerja.

\section{Rumusan Masalah}

Dari latar belakang masalah tersebut maka penulis merumuskan masalah sebagai berikut Bagaimana kebijakan ekonomi yang diambil pimpinan untuk mendorong tingkat kedisiplinan pegawai negeri sipil jika dilihat dari penerapan sistem biometrik di perguruan tinggi islam negeri.

\section{Landasan Teoritik}

\section{a. Etika Pegawai}

Seorang pegawai suatu instansi baik itu swasta maupun pemerintahan secara spesifik nilai-nilai dasar dan etika dalam bekerja. Dimana etika tersebut sebagai elemen utama dalam instansi tersebut. Dalam pemerintah etika bekerja telah diatur dalam Peraturan Pemerintah Nomor 42 Tahun 2004 Tentang Pembinaan Jiwa Korps dan Kode Etik PNS. Nilainilai dasar tersebut yang harus dijunjung tinggi oleh setiap PNS, yaitu:

a. Ketaqwaan kepada Tuhan Yang Maha Esa;

b. Kesetiaan dan ketaatan kepada Pancasila dan Undang-undang Dasar 1945;

c. Semangat nasionalisme;

d. Mengutamakan kepentingan Negara di atas kepentingan pribadi atau golongan;

e. Ketaatan terhadap hukum dan peraturan perundang-undangan;

f. Penghormatan terhadap hak asasi manusia;

g. Tidak diskriminatif;

h. Profesionalisme, netralitas dan bermoral tinggi; dan

i. Semangat jiwa korps. 


\section{b. Produktivitas}

Seorang pegawai harus memiliki produktivitas yang tinggi. Definisi produktifitas menurut Ambar ${ }^{5}$ adalah perbandingan antara hasil yang dicapai dengan peran serta tenaga kerja per satuan waktu. Pengertian tersebut menunjukkan adanya kertekaitan antara waktu yang digunakan dengan hasil kerja. Hal ini tidak lepas dengan efisiensi dan efektivitas. Pengukuran kinerja menurut Sastrohadiwiryo ${ }^{6}$ meliputi beberapa criteria, antara lain:

- Kualitas kerja (quality of qork) yaitu kualitas kerja yang dicapai berdasarkan syarat-syarat kesesuian dan kesepiannya.

- Kuantitas kerja (quantity of work) yaitu jumlah kerja yang dilakukan dalam suatu periode waktu yang telah ditentukan.

- Kreatifitas yaitu keaslinan gagasan yang dimunculkan dalam tindakantindakan untuk menyelesaikan persoalan yang timbul.

- Kerja sama (corporation) yaitu kesadaran untuk bekerja sama dengan yang lain (sesame anggota organisasi)

- Pengetahuan tentang pekerjaan (knowledge of job) yaitu luasnya pengetahuan mengenai pekerjaan dan ketrampilan

- Ketergantungan (dependen ability) yaitu kesadaran dan dapat dipercaya dalam hal kehadiran dan penyelesaian pekerjaan.

- Inisiatif (initiative) yaitu tindakan dalam menyelesaikan pekerjaan.

- Personal kualitas yaitu menyangkut kepribadian, kepemimpinan, keramahan dan intergritas pribadi.

\section{c. Tingkat Absensi (Tingkat Kehadiran Karyawan).}

Semangat kerja dapat diukur melalui absensi / presensi pegawai ditempat kerja, tanggung jawabnya terhadap pekerjaan, disiplin kerja, kerja sama dengan pimpinan atau teman sejawat dalam organisasi serta tingkat produktivitas kerjanya. (Hasley, 1 992;67). Untuk mengukur tinggi

\footnotetext{
${ }^{5}$ Ambar T Sulistiyani \& Rosyidah, Manajemen Sumber Daya Manusia, Teori Dan Pengembangan Dalam Konteks Organisasi Publik, Yogjakarta: Graham Ilmu. 2003, hal: 199

6 Siswanto Sastrohadiwiryo, Manajemen Tenaga Kerja Indonesia Pendekatan Administrasi Dan Operasional, Jakarta: PT Bumi Aksara, 2002, Hal: 236
} 
Dampak Ekonomi dari Penerapan Sistem Biometrik

rendahnya semangat kerja pegawai dapat melalui unsur-unsur semangat kerja tersebut yang meliputi : Presensi (tingkat kehadiran), Disiplin Kerja, Kerja Sama, dan Tanggung Jawab.

Presensi merupakan kehadiran pegawai yang berkenaan dengan tugas dan kewajibannya. Pada umumnya instasi atau lembaga selalu memperhatikan pegawainya untuk datang dan pulang tepat waktu, sehingga pekerjaan tidak tertunda. Ketidak hadiran seorang pegawai akan berpengaruh terhadap produktivitas kerja, sehingga instansi atau lembaga tidak bisa mencapai tujuan secara optimal. Presensi atau kehadiran pegawai dapat diukur melalui :

a. Kehadiran karyawan ditempat kerja.

b. Ketepatan keryawan datang atau pulang

c. Kehadiran pegawai apabila mendapat undangan untuk mengikuti kegiatan atau acara dalam instansi.

Dengan adanya tingkat absensi yang baik maka dapat meningkatkan disiplin pegawai. Sedangkan yang dimaksud dengan disiplin adalah suatu sikap, tingkah laku dan perbuatan yang sesuai dengan peraturan dari perusahan atau instansi baik tertulis maupun tidak (Nitisemito, 1982; 199).

\section{d. Tingkat disiplin kerja}

Mengukur kedidiplinan pegawai dapat dilihat dari:

- Ketepatan waktu,

- Mampu memanfaatkan dan menggerakkan perlengkapan dengan baik,

- Menghasilkan pekerjaan yang memuaskan,

- Mengikuti cara kerja yang ditentukan oleh perusahaan (kepatuhan pada peraturan)

- Memiliki tanggung jawab yang tinggi.

Ketentuan yang berhubungan dengan waktu dan kehadiran pegawai biasanya diatur dengan ketentuan-ketentuan sbb :

- Penetapan waktu kerja didasarkan kepada kebutuhan-kebutuhan perlu dengan mengindahkan peraturan perundang-undangan yang berlaku. 
- Jumlah jam kerja bagi karyawan adalah 40 hari seminggu.

- Jam istirahat tidak dihitung sebagai jam kerja.

- Setiap karyawan wajib hadir dan mulai bekerja pada waktu yang tidak ditetapkan.

- Kehadiran karyawan dicatat dengan kartu hadir (lime Card) pada saat maupun pada saat pulang kerja.

- Pengisian kartu hadir (Time Card) harus dilakukan oleh karyawan yang bersangkutan sendiri. Pengisian yang dilakukan oleh orang lain merupakan pelanggaran kedisiplinan, dan hal tersebut akan dikenakan sanksi sesuai peraturan yang berlaku.

- Keterlambatan masuk kerja atau meninggalkan tempat kerja sebelum jam kerja berakhir dianggap sebagai tindakan ketidak disiplinan dan merupakan pelanggaran tata tertib, kecuali dengan izin atasan langsung dan karena alasan-alasan yang dapat diterima.

- Karyawan yang tidak masuk kerja kerena sakit atau karena alasan lain yang dapat diterima Perusahaan, wajib memberitahukan kepada atasannya pada hasil tersebut secara tertulis atau telephone selambatlambatnya pada hari kerja berikutnya.

- Jika tidak hadir kerja karena sakit, maka wajib membawa surat keterangan dokter setelah Ia wasuk kerja kembali.

- Jika ketidak hadiran karena hal-hal lain, ia diwajibkan membuat pemberitahuan tertulis dengan alasan yang dapat dipertanggungjawabkan.

- Karyawan yang tidak mengindahkan kewajiban tersebut dianggap mungkir dan akan dikenakan sanksi.

\section{e. Hubungan Tingkat kehadiran Karyawan dan Disiplin Kerja}

Dalam pelaksanaan disiplin kerja karyawan, peranan pimpinan sangat besar dan menentukan. Kelemahan pelaksanaan disiplin selama ini adalah lemahnya pengawasan pimpinan terhadap pembinaan disiplin karyawan. Padahal disiplin kerja memegang peranan penting bagi kelangsungan kerja organisasi. 
Dampak Ekonomi dari Penerapan Sistem Biometrik

Dengan disiplin kerja yang tinggi dari karyawan akan berdampak positif terhadap tercapai efektivitas dan efisien kerja yang berarti produktivitas kerja akan tercapai pula.

Indikator pertama di atas menyebutkan kepatuhan karyawan terhadap jam-jam kerja kantor. Ini berarti tingkat kehadiran karyawan juga sangat menentukan produktivitas kerja. Semakin tinggi tingkat kehadiran karyawan semakin tinggi pula tingkat keberhasilan organisasi. Oleh karena itu kehadiran karyawan merupakan faktor penting dalam pelaksanaan disiplin kerja.

Kaitannya dengan tingkat kehadiran ini, Winaya (1983) memberikan ukuran/kriteria disiplin karyawan sebagai berikut : "Bilamana tingkat absensi atau ketidakhadiran per bulan mencapai 2-3\%, maka dikatakan karyawan mempunyai disiplin yang tinggi. Bilamana tingkat absensi mencapai 15-20\% per bulan, maka dikatakan disiplin karyawan rendah, dan apabila berada di antara kedua ketentuan di atas, maka tingkat disiplin karyawan dapat dikatakan sedang".

Ukuran atau kriteria disiplin karyawan juga dikemukakan oleh Sujono (1985), dengan memberikan kriteria yang lebih luas sebagai berikut: "Disiplin yang sejati adalah apabila karyawan datang di kantor dengan teratur dan tepat pada waktunya. Apabila mereka berpakaian serba baik pada tempat bekerjanya. Apabila mereka menggunakan bahan-bahan dan perlengkapan dengan hati-hati, apabila mereka menghasilkan jumlah dan kualitas pekerjaan yang memuaskan dan mengikuti cara bekerja yang ditentukan oleh kantor atau perusahaan dan apabila mereka menyelesaikan pekerjaan yang sangat tinggi. Ukuran ini harus diperhatikan atas pekerjaan sehari-hari”.

Dengan kriteria sekaligus indikator seperti yang disebutkan di atas, maka peranan disiplin sangat besar pengaruhnya terhadap kinerja karyawan. Dan jika semua kriteria di atas terpenuhi, maka produktivitas kerja akan semakin tinggi. 


\section{Hipotesis}

Hipotesa model penelitian:

$\mathrm{H}_{0}=$ variable finger print, kompensasi dan motivasi tidak berpengaruh secara signifikan terhadap tingkat kedisiplinan pegawai dan dosen di Fakultas Ekonomi dan Bisnis Islam IAIN Walisongo Semarang.

$\mathrm{H}_{1}=$ variable finger print mempengaruhi perhitungan uang makan sebagai salah satu kompensasi yang diberikan pemerintah kepada dosen dan pegawai.

$\mathrm{H}_{2}=$ variable finger print mempengaruhi diri pribadi dosen dan pegawai sebagai salah satu motivasi untuk meningkatkan kedisiplinan.

$\mathrm{H}_{3 .}=$ variable pemberian kompensasi berupa uang makan mempengaruhi diri pribadi dosen dan pegawai sebagai salah satu motivasi untuk meningkatkan kedisiplinan.

$\mathrm{H}_{4}=$ variable perhitungan absensi melalui finger print mempengaruhi tingkat kedisiplinan pegawai dan dosen Fakultas Ekonomi dan Bisnis Islam IAIN Walisongo Semarang.

$\mathrm{H}_{5}=$ variable pemberian kompensasi berupa uang makan mempengaruhi tingkat kedisiplinan pegawai dan dosen Fakultas Ekonomi dan Bisnis Islam IAIN Walisongo Semarang

$\mathrm{H}_{6}=$ variable motivasi diri sendiri mempengaruhi tingkat kedisiplinan pegawai dan dosen Fakultas Ekonomi dan Bisnis Islam IAIN Walisongo Semarang

\section{Metodologi Penelitian}

Pengambilan sampel dengan tujuan yang diinginkan peneliti. ${ }^{7}$ Seluruh pegawai dan dosen di Fakultas Ekonomi dan Bisnis Islam berjumlah 39 orang, dan dari jumlah tersebut yang menjadi Pegawai Negeri Sipil IAIN Walisongo

${ }^{7}$ Husaini usman \& R. Purnomo S.A, Pengantar Statistika, Penerbit Bumi Aksara, Jakarta, 2008, hal: 181

Volume V/Edisi 1/Mei 2014 
Dampak Ekonomi dari Penerapan Sistem Biometrik

Semarang berjumlah 34 orang sedangkan 5 orang pegawai BLU. Sehingga yang menjadi sampel adalah yang sudah PNS yaitu 34 orang.

\section{Pembahasan}

Absensi yang dilakukan semua pegawai di Fakultas Ekonomi dan Bisnis Islam dilakukan pada 5 hari kerja yaitu senin-jumat. Untuk hari seninkamis absensi datang / masuk kerja mulai pukul 07.30 - 16.00 WIB, sedangkan hari jumat mulai pukul $07.00-16.00$ WIB. Jika pegawai ada yang datang terlambat dari jam tersebut dan pulang sebelum jam tersebut maka pegawai tersebut melanggar ketentuan yang telah diberlakukan oleh pemerintah. Hal ini dapat dikalkumulasi oleh alat finger print. Ketidaksesuain kedatangan dan kepulangan pada jam kerja berdampak pada pemberian uang makan. Jika dalam absen tidak tepat maka pegawai tidak mendapatkan uang makan.

1. Uji Asumsi Klasik

Untuk uji asumsi klasik dibutuhkan tabel 2.

Tabel 2

Nilai regresi

\begin{tabular}{|c|c|c|c|c|c|}
\hline \multicolumn{6}{|c|}{ Persamaan I $\rightarrow Y_{a}=\alpha+\beta_{1} X_{1}+\beta_{2} X_{2}+\beta_{3} X_{3}+\varepsilon$} \\
\hline Variabel & $\begin{array}{l}\text { Koefisien } \\
(\beta)\end{array}$ & $\begin{array}{l}\text { Nilai } \\
\mathrm{t}\end{array}$ & $\begin{array}{l}\text { Signifikansi } \\
\mathrm{t}\end{array}$ & VIF & $\mathrm{CI}$ \\
\hline Konstanta & 1,691 & 3,024 & 0,005 & - & 1,000 \\
\hline $\begin{array}{l}\text { Finger print } \\
\left(\mathrm{X}_{1}\right)\end{array}$ & $-0,069$ & $-\overline{0}, 516$ & 0,609 & 1,692 & 11,637 \\
\hline $\begin{array}{l}\text { Kompensasi } \\
\left(\mathrm{X}_{2)}\right.\end{array}$ & 0,315 & 2,088 & 0,44 & 1,520 & 15,390 \\
\hline $\begin{array}{l}\text { Motivasi } \\
\left(\mathrm{X}_{3)}\right.\end{array}$ & 0,138 & 1,325 & 0,194 & 1,156 & 20,953 \\
\hline $\mathrm{R}^{2}$ & $17,8 \%$ & & & & \\
\hline DW test & 2,235 & & & & \\
\hline \multicolumn{6}{|c|}{ Persamaan II $\rightarrow X_{3}=\lambda+\beta_{4} X_{1}+\beta_{5} X_{2 .}+\varepsilon$} \\
\hline Konstanta & 2,274 & 2,848 & 0,007 & - & 1,000 \\
\hline $\begin{array}{l}\text { Finger print } \\
\left(\mathrm{X}_{1}\right)\end{array}$ & 0,408 & 2,058 & 0,047 & 1,518 & 13,296 \\
\hline
\end{tabular}




\begin{tabular}{|l|l|l|l|l|l|}
\hline $\begin{array}{l}\text { Kompensasi } \\
\left(\mathrm{X}_{2}\right)\end{array}$ & $-0,046$ & $\begin{array}{l}- \\
0,192\end{array}$ & 0,190 & 1,518 & 17,387 \\
\cline { 1 - 2 } $\mathrm{R}^{2}$ & $13,5 \%$ & \multicolumn{4}{|l}{} \\
\cline { 1 - 2 } DW test & 1,839 & & & \\
\hline
\end{tabular}

Sumber : Olah data di olah, lampiran

Uji asumsi klasik meliputi 3 uji yaitu:

- Multikolinearity

Untuk uji multikolinearity peneliti menggunakan uji VIF dan CI.

Persamaan I.

Dimana untuk persamaan I nilai VIF variable independent finger print (1,692), kompensasi $(1,520)$ dan motivasi $(1,156)<10$. Sedangkan nilai CI variable independent finger print $(11,637)$, kompensasi $(15,390)$ dan motivasi $(20,953)<30$. Maka dapat disimpulkan bahwa variebl-variabel independent pada persamaan I tidak mengandung penyimpangan multikolinearity.

Persamaan II

Dimana untuk persamaan II nilai VIF variable independent finger print $(1,518)$, kompensasi $(1,518)<10$. Sedangkan nilai CI variable independent finger print $(13,296)$, kompensasi $(17,387)<30$. Maka dapat disimpulkan bahwa variebl-variabel independent pada persamaan II tidak mengandung penyimpangan multikolinearity.

- Autokorelasi

Persamaan $\mathrm{I}, \mathrm{k}=4$, du $=1,285, \mathrm{dl}=1,721$ 
Dampak Ekonomi dari Penerapan Sistem Biometrik

Grafik 1

Nilai Durbin Watson Persamaan I

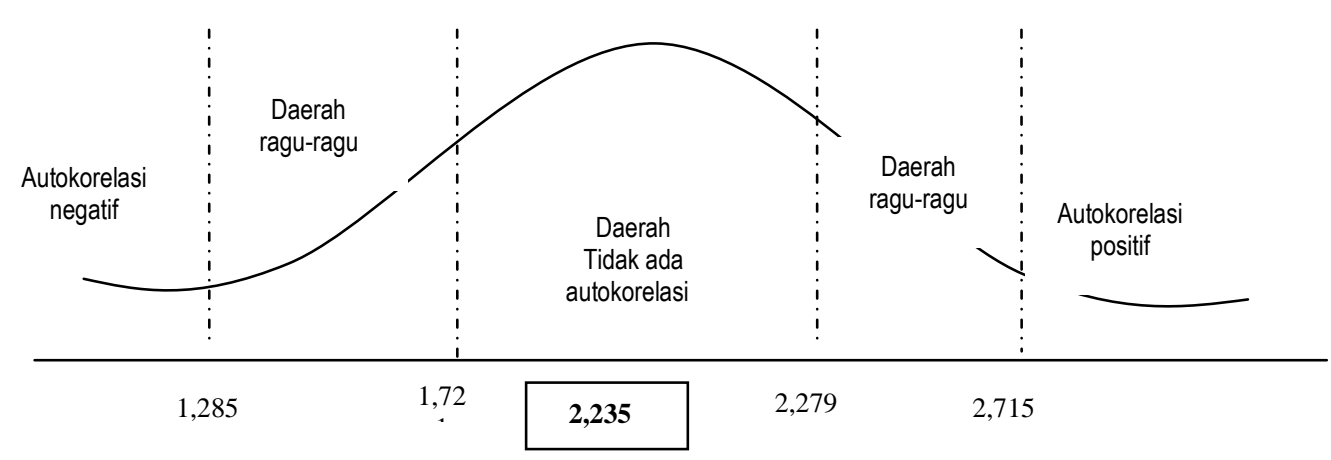

Dilihat dari grafik 1 dapat diketahui bahwa hasil uji DW untuk persamaan I nilainya $(2,245)$ terletak diantara $\mathrm{du} \leq \mathrm{dw}$ hitung $\leq 4$-du atau $1,721 \leq 2,245 \leq 2,279$. Daerah tersebut merupakan daerah bebas autokorelasi dimana menerima Ho atau menerima H1. Sehingga dapat disimpulkan bahwa variable finger print, kompensasi, motivasi dan kedisiplinan data yang digunakan bebas asumsi autokorelasi.

Grafik 2

Nilai Durbin Watson Persamaan II

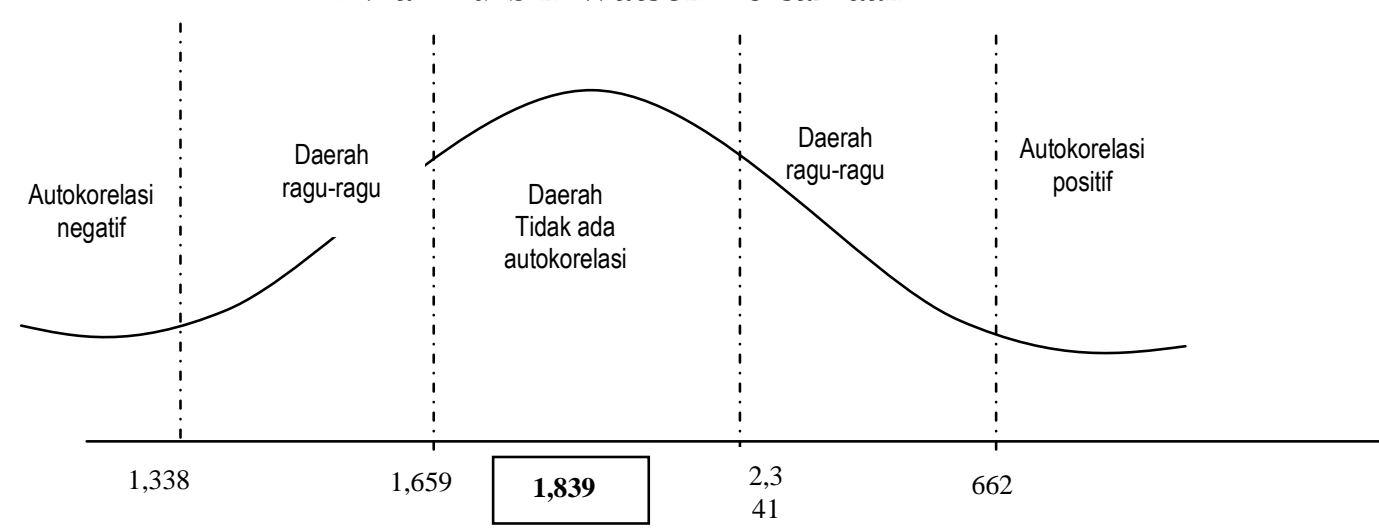


Persamaa II memiliki nilai tabel dw sebagai berikut:

$\mathrm{k}=3, \mathrm{du}=1,338, \mathrm{dl}=1,659$

Grafik 2 dapat diketahui bahwa hasil uji DW untuk persamaan II nilainya $(1,839)$ terletak diantara du $\leq \mathrm{dw}$ hitung $\leq 4$-du atau 1,659 $\leq$ $1,839 \leq 2,341$. Daerah tersebut merupakan daerah bebas autokorelasi dimana menerima Ho atau menerima H1. Sehingga dapat disimpulkan bahwa variable finger print, kompensasi dan motivasi data yang digunakan bebas asumsi autokorelasi.

- Heteroskedastisitas

Uji heteroskedastisitas yang digunakan dalam peelitian ini adalah menggunakan uji scatter plot. Hasil scatter plot dari persamaan I dan II sebagai berikut:

\section{Grafik 3}

Grafik scatter plot persamaan I dan II
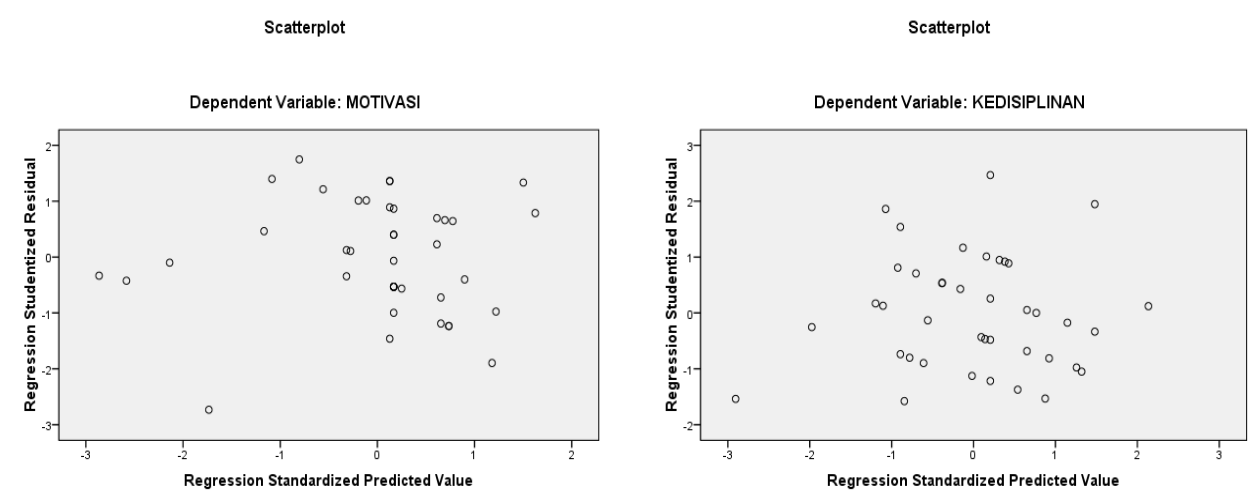

Dari grafik 3 titik-titik yang ada di scatter plot I dan II kondisinya menyebar itu berarti hasil kuesionare dari responden telah memenuhi asumsi bebas heteroskedastisitas.

2. Uji beda ( $t)$

Membaca uji beda $t$ dilakukan untuk melihat apakah peneliti akan menerima atau menolak H0. Dalam penelitian ini uji beda t sebagai berikut:: 
Dampak Ekonomi dari Penerapan Sistem Biometrik

- Persamaan I

- Dengan melihat tabel 2 dapat diketahui bahwa nilai t hitung variabel finger print sebesar -0,516 dimana nilai tersebut $<$ nilai t tabel / kritis dengan $\alpha=5 \%$ two tail yaitu sebesar 2,021 serta signifikansi nilai t sebesar 0,609>0,05 maka dapat disimpulkan bahwa penelitian ini menerima $\mathrm{H} 0$ atau variable finger print tidak mempengaruhi tingkat kedisiplinan PNS Fakultas Ekonomi dan Bisnis Islam.

- Sedangkan nilai t hitung variable kompensasi sebesar 2,088> nilai t kritisnya $(2,021)$ serta signifikansi t sebesar $0,044<0,05$ maka dapat disimpulkan bahwa penelitian ini menerima $\mathrm{H} 1$ atau variable kompensasi pemberian uang makan mempengaruhi tingkat kedisiplinan PNS Fakultas Ekonomi dan Bisnis Islam.

- Dan nilai $\mathrm{t}$ hitung variable motivasi sebesar $1,325<$ nilai $\mathrm{t}$ kritisnya (2,021) serta signifikansi t sebesar 0,194 > 0,05 maka dapat disimpulkan bahwa penelitian ini menerima $\mathrm{H} 0$ atau variable motivasi yang diberikan pimpinan Fakultas Ekonomi dan Bisnis Islam dalam mekritisi pegawainya akan absensi tidak mempengaruhi tingkat kedisiplinan PNS Fakultas Ekonomi dan Bisnis Islam.

- Persamaan II

- Sedangkan untuk persamaan II dapat disimpulkan bahwa nilai t hitung variabel finger print sebesar 2,056 dimana nilai tersebut $>$ nilai $\mathrm{t}$ tabel / kritis sebesar 2,021 serta signifikansi nilai $\mathrm{t}$ sebesar 0,047<0,05 maka dapat disimpulkan bahwa penelitian ini menolak $\mathrm{HO}$ atau variable finger print mempengaruhi motivasi pimpinan Fakultas Ekonomi dan Bisnis Islam dalam hal mendukung pemberlakukan absensi finger print.

- Dan nilai t hitung variable kompensasi sebesar -0,192 > nilai t kritisnya $(2,021)$ serta signifikansi t sebesar $0,849>0,05$ maka dapat disimpulkan bahwa penelitian ini menerima $\mathrm{H} 0$ atau variable kompensasi pemberian uang makan tidak mempengaruhi motivasi pimpinan Fakultas Ekonomi dan Bisnis 
Islam dalam hal mendukung pemberlakukan absensi finger print.

- Kesimpulan umum mengenai uji t nya adalah:

- Pemberlakukan absensi dengan menggunakan finger print tidak mempengaruhi PNS Fakultas Ekonomi dan Bisnis Islam dalam melakukan absensi setiap harinya namun secara tidak langsung pemberlakuan ansensi finger print mempengaruhi pimpinan dalam memberikan motivasi kepada pegawainya yaitu berupa motivasi yang dibuat pimpinan Fakultas Ekonomi dan Bisnis Islam. Motivasi-motivasi tersebut diantaranya: dikeluarkannya surat rekapan absensi per semester kepada masing-masing pegawai Fakultas Ekonomi dan Bisnis Islam. Dimana di dalam rekapan tersebut berisi mengenai keterlambatan jam datang, ketidak tepatan jam pulang kerja bahkan jumlah hari ijin dan tidak ijin atau bolos.

- Variable kompensasi berupa pemberian uang makan sangat mempengaruhi kedisiplinan pegawai Fakultas Ekonomi dan Bisnis Islam atau rajin tidaknya, tepat tidaknya pegawai dalam melakukan absen kerja. Semakin besar jumlah uang makan yang diberikan maka pegawai Fakultas Ekonomi dan Bisnis Islam akan semakin rajin dan tepat waktu dalam melakukan absen kerja. Namun pemberian uang makan tidak mempengaruhi pimpinan dalam mendukung pegawainya untuk lebih rajin bekerja. Karena hal itu sudah hak masing-masing pegawai untuk datang kerja tepat waktu. Dan bukan hak pimpinan.

3. Koefisien determinasi $\left(\mathrm{R}^{2}\right)$

Nilai koefisien $\mathrm{R}^{2}$ untuk persamaan I sebesar 17,8\%. Yang berarti variable finger print, kompensasi dan motivasi mempengaruhi tingkat kedisiplinan pegawai secara bersama-sama sebesar 17,8 \% sedangkan sisanya $82,2 \%$ dipengaruhi variable lain.

Sedangkan koefisien $\mathrm{R}^{2}$ untuk persamaan II sebesar 13,5\%. Yang berarti variable finger print, kompensasi mempengaruhi motivasi 
Dampak Ekonomi dari Penerapan Sistem Biometrik

yang diberikan pimpinan kepada pegawai secara bersama-sama sebesar 13,5\% sedangkan sisanya 86,5\% dipengaruhi variable lain.

Untuk perhitungan nilai residu $(\varepsilon)$ yaitu:

$$
\begin{aligned}
& \varepsilon 1=\sqrt{1-0,178}=\sqrt{0,822}=0,906 \\
& \varepsilon 2=\sqrt{1-0,135}=\sqrt{0,865}=0,930
\end{aligned}
$$

Nilai residu / variable pengganggu persamaan I sebesar 90,6\% sedangkan variable pengganggu persamaan II sebesar $93 \%$.

4. Interpertasi model regresi

Model regresi dengan koefisien standardized adalah sebagai berikut:

$$
\begin{aligned}
& \mathrm{Y}=-0,101 \mathrm{X}_{1}+0,389 \mathrm{X}_{2}+0,215 \mathrm{X}_{3}+\varepsilon \\
& \mathrm{X}_{3}=0,388 \mathrm{X}_{1}-0,036 \mathrm{X}_{2 .}+\varepsilon \\
& \mathrm{X}_{2}=0,584 \mathrm{X}_{1}+\varepsilon
\end{aligned}
$$

Persamaan tersebut memiliki arti sebagai berikut:

- Pengaruh langsung pemberian kompensasi uang makan terhadap kedisiplinan sebesar 0,389 .

- Pengaruh tidak langsungnya yaitu:

$\mathrm{X}_{1}$ ke $\mathrm{X}_{3}$ ke $\mathrm{Y}=0,584 \times 0,389=0,227$

$\mathrm{X}_{1}$ ke $\mathrm{X}_{2}$ ke $\mathrm{X}_{3}$ ke $\mathrm{Y}=0,584 \times-0,036 \times 0,215=$ 0,004

$\mathrm{X}_{1}$ ke $\mathrm{X}_{3}$ ke $\mathrm{Y}=0,388 \times 0,215=0,083$

- Maka pengaruh pemberian kompensasi uang makan terhadap kedisiplinan sebesar $0,389+0,227-(-0,004)+0,083=0,703$

- Dapat disimpulkan bahwa pemberian uang makan sangat mempengaruhi tingkat rajin tidaknya pegawai untuk disiplin absen sebesar $70,3 \%$.

\section{Kesimpulan}

Penelitian telah menghasilkan beberapa kesimpulan selain permasalahan yang ada Dan kesimpulan-kesimpulan berikut diharapkan peneliti dapat memberikan kontribusi kepada pihak Fakultas Ekonomi dan Bisnis Islam 
ataupun pihak - pihak lain yang berkepentingan dalam membuat kebijakankebijakan Fakultas di kemudian hari. Kesimpulan tersebut diantaranya :

1. Korelasi antara variable independent dengan variable dependent (tingkat kedisiplinan)

a. Pemberlakuan system biometric (finger print) di Fakultas Ekonomi dan Bisnis Islam IAIN Walisongo Semarang tidak mempengaruhi pegawai khususnya dosen untuk disiplin absen kerja sehari 7,5 jam. Hal ini dibuktikan dengan nilai signifikansi uji t sebesar 0,609>0,05 sehingga menerima Ho.

Alasan ini kenapa tidak mempengaruhi menurut peneliti adalah bahwa dosen selain tugas mengajar juga ada tugas tambahan lainnya di luar mengajar diantara pengabdian masyarakat yang terkadang mewajibkan dosen untuk tidak bisa absen ke kantor, selain itu dinas luar tugas dari pimpinan yang menyebabkan tidak boleh absen.

b. Pemberian kompensasi (uang makan) mempengaruhi pegawai Fakultas Ekonomi dan Bisnis Islam untuk meningkatkan kedisiplinan mereka dalam absen. Hal ini dibuktikan dengan nilai signifikansi $\mathrm{t}$ $0,044<0,05$ sehingga menerima $\mathrm{H} 1$.

Jika uang makan ditambah Rp 1,00 akan memicu semangat pegawai untuk rajin/disiplin absen sebesar $0,315 \%$.

c. Sedangkan motivasi yang diberikan pimpinan Fakultas Ekonomi dan Bisnis Islam supaya pegawainya lebih rajin masuk kerja tidak mempengaruhi pegawai untuk absen. Hal ini dibuktikan dengan signifikansi t 0,194 > 0,05 dimana menerima H0.

Jawaban penelitian ini dibuktikan dengan adanya pemberian rekap absen pegawai selama bulan janurai-April 2014 dimana di dalamnya terdapat berapa kali dia masuk tepat waktu, pulang tepat waktu, absen ijin hingga tidak masuk kerja tanpa ijin. Hal ini dilakukan oleh pimpinan Fakultas Ekonomi dan Bisnis Islam supaya pegawai dan dosen Fakultas Ekonomi dan Bisnis Islam mengetahui seberapa besar ketidak disiplinan mereka masuk kerja. Namun kebijakan terebut ternyata tidak mempengaruhi pegawai khususnya dosen. Hal ini kemungkinan alas an yang ada pada point a). 
Dampak Ekonomi dari Penerapan Sistem Biometrik

2. Korelasi antara variable independent dengan variable moderator (motivasi)

a. Pemberlakuan system biometric (finger print) ternyata mempengaruhi pimpinan dalam memotivasi pegawainya untuk rajin dan disiplin dalam melakukan absensi setiap harinya. Hal ini dibuktikan dengan nilai signifikanasi t sebesar 0,047<0,05 atau penelitian menerima H1. Semakin ketat pemberlakuan absensi kerja dari pemerintah kepada pegawai dan dosen maka semakin tinggi pimpinan Fakultas Ekonomi dan Bisnis Islam memotivasi pegawainya untuk lebih disiplin sebesar $0,408 \%$.

Hal ini nyata dengan keadaan di fakultas. Setelah ada pemberlakuan finger print pimpinan Fakultas Ekonomi dan Bisnis Islam giat mendorong pegawainya baik administrasi maupun dosen untuk lebih disiplin dalam absen tiap harinya 7,5 jam. Motivasi yang dilakukan berupa pimpinan mengeluarkan surat edaran berupa rekapan absensi pegawai dan dosen, terkadang pimpinan menunggu di depan mesin finger print untuk mengamati pegawai dan dosen yang berangkat terlambat. Hal ini secara tidak langsung memunculkan rasa ewuh pakewnh dari mereka karena diamati pimpinan langsung.

b. Untuk pemberian kompensasi (uang makan) ternyata tidak mempengaruhi pimpinan untuk memotivasi pegawai dan dosen. Hal ini dibuktikan dengan nilai signifikansi t $0,849>0,05$, atau menerima HO.

Karena untuk urusan mencari kompensasi itu merupakan hak masingmasing pegawai dan pimpinan hanya sebagai pendorong saja. Jika mereka tidak melakukan absen maka mereka sendirilah yang tidak akan mendapatkan uang makan bukan pihak pimpinan.

3. Kebijakan yang diambil pimpinan atas dampak penetapan system biometric dalam hal ekonomi keuangan adalah:

a. Pimpinan diharapkan mendorong pegawai dan dosennya untuk lebih memprhatikan keberadaan system biometric yang digunakan karena hasil print out system ini lah yang akan digunkan untuk menghitung uang makan atau kompensasi yang diterima mereka. 
b. Pemotongan uang makan perlu dilakukan untuk melatih kedisiplinan pegawai dan dosen PNS.

c. Pemberian apresiasi kepada pegawai dan dosen yang absen selalu tepat waktu dan bekerja maksimal dalam menyelesaikan pekerjaannya. Apresiasi tersebut berbentuk bingkisan atau uang.

d. Melengkapi fasilitas yang dibutuhkan pegawai dan dosen. Seperti ruang dosen ber AC, almari (loker) dosen, dispenser minum serta perlengkapannya (gula, teh, kopi), mushola, makan siang (disediakan dengan iuran bersama) dan wifi. Hal ini disediakan supaya dosen dan pegawai kebutuhan pribadinya terjamin di kantor sehingga tidak perlu keluar. 
Dampak. Ekonomi dari Penerapan Sistem Biometrik

\section{DAFTAR PUSTAKA}

Aba Yazid, Pengaruh Gaji Dan Insentif Terbadap Produktivitas Kerja Karyawan Pad Cv Indo Perkasa Situbondo, Skripsi, Malang, 2008.

Agus Widarjono, Analisis Statistic Multivariate Terapan, UPP STIM YKPN, Yogjakarta, 2010,

Ambar T Sulistiyani \& Rosyidah, Manajemen Sumber Daya Manusia, Teori Dan Pengembangan Dalam Konteks Organisasi Publik, Yogjakarta: Graham Ilmu. 2003

Djumadi, Hukum Perburuan Perjanjian Kerja, PT. Raja Grafindo Persada, Jakarta, 2004,

Erna Maeyasari, Pengaruh Efektivitas Penerapan Absensi Finger Print Terbadap Disiplin Pegawai Negeri Sipil Di Secretariat Daerah Kabupaten Lebak, Universitas Sultas Ageng Tirtayasa Serang, 2012

Hasley, George D, Bagaimana Memimpin Dan Mengawasi Pegawai Anda, Cetakan Ketiga Jakarta: Penerbit: Rineka Cipta. 1994

Husaini usman \& R. Purnomo S.A, Pengantar Statistika, Penerbit Bumi Aksara, Jakarta, 2008

Imam Ghozali, 2011, Aplikasi Analisis Multivariate Dengan Program IBM SPSS 19, Undip, Semarang

Imam Ghozali, Analisis Multivariate dengan Program IBM SPSS 19.

Ismi Herdyanti, Hubungan Kompensasi Dengan Kinerja Karyawan, Universitas Gunadharma, 2013

Madjloes, Perlakuan Hukum Pidana Terbadap Pegawai Negeri, Citra Budaya, Jakarta,1980,340 mad p,Indonesia

Sastrohadiwiryo, Dr. B. Siswanto, Manajemen Tenaga Kerja Indonesia Pendekatan Administrasi Dan Operasional, Jakarta : PT Bumi Aksara, cet Ke II, 2002. 
Sinungan, Muchdarsah, Produktivitas: Apa Dan Bagaimana, Jakarta: PT Bumi Aksara, 2008

Siagian, prof. Dr. Sondang, Manajemen Sumber Daya Manusia, Jakarta: PT Bumi Aksara, 2003

Sugiyono, Metodologi Penelitian Kuantitatif Kualitatif, Bandung: Alfabeta, 2008

Suharyadi dan Purwanto S.K, Statistiks Untuk Ekonomi \& Kenangan Modern, Salemba Empat, Jakarta, 2004

Susilo Martoyo. Kol. (Purn), SE., Manajemen Sumber Daya Manusia edisi 4, BPFE, Yogjakarta.

Tigor Pangondian, Pengaruh Penempatan, Kompensasi, Kesempatan Berprestasi, Komunikasi Dan Lingkungan Kerja Terbadap Semangat Kerja Karyawan Kimia Farma Di Bali, Thesis Program Magister Studi Manajemen Universitas Udayana Denpasar, 2011

Tjatur Wahyuhadi, Pengarub Lingkungan Kerja, Teladan Pimpinan Dan Kompensasi Terhadap Disiplin Kerja Karyawan Di Dinas Kesebatan Kabupaten Bangli, Thesis Pada Program Magister Manajemen Universitas Udayana Denpasar, 2005

Yatim Rianto, Metodologi Penelitian Suatu Tujuan Dasar, Surabaya: Gaung Persada Press, 1996 
Dampak Ekonomi dari Penerapan Sistem Biometrik 